\title{
UNDERLYING FACTORS AFFECTING UTILIZATION OF COMPUTER - BASED INTERNET TECHNOLOGIES BY AGRICULTURAL EXTENSION PERSONEL IN AKWA IBOM, NIGER DELTA, NIGERIA
}

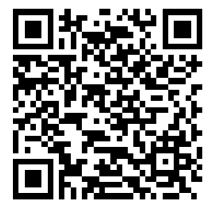

\author{
Akpabio Iniobong Aniefiok ${ }^{1}{ }^{\mathbb{4}}$, Glory Emmanuel Edet 2 , Joan Ekpo Cyril ${ }^{3}$ \\ *1, 2 Department of Agricultural Economics and Extension University of Uyo, Akwa Ibom State, \\ Nigeria \\ ${ }^{3}$ Community and Social Development Project in Akwa Ibom StateUyo, Akwa Ibom State, Nigeria
}

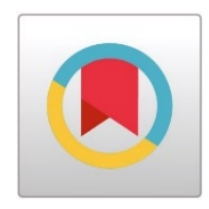

DOI: https://doi.org/10.29121/granthaalayah.v9.i1.2021.3143

Article Type: Research Article

Article Citation: Akpabio Iniobong Aniefiok, Glory Emmanuel Edet, and Joan Ekpo Cyril. (2021).

UNDERLYING FACTORS AFFECTING UTILIZATION OF COMPUTER BASED INTERNET TECHNOLOGIES BY AGRICULTURAL EXTENSION PERSONEL IN AKWA IBOM, NIGER DELTA, NIGERIA. International Journal of Research GRANTHAALAYAH, 9(1), 399-350. https://doi.org/10.29121/granthaa layah.v9.i1.2021.3143

Received Date: 25 December 2021

Accepted Date: 31 January 2021

Keywords:

Computer-Based Internet

Technologies

Utilization

Underlying Factors

Extension Personnel

Akwa Ibom State

\section{ABSTRACT}

The study sought to examine factors affecting utilization of Computer Based Internet Technologies (CBIT) by extension personnel in Akwa Ibom State, Nigeria. Relevant data were obtained from 180 respondents, while data analyses were achieved with the aid of descriptive and inferential statistical tools. Findings showed that $57.8 \%$ of the respondents were male, $91.7 \%$ were married, with a mean age of 43years, while $62.8 \%$ respondents had no formal computer training. It was also revealed that, of the nine surveyed CBIT facilities and applications, only mobile phones were highly utilized, while I-pads/laptops and YouTube were the least utilized. It was also revealed that $62.8 \%$ respondents indicated that they had a low level of CBIT utilization, while level of CBIT utilisation was found to be influenced by financial, training, policy/personal barriers, social, technical and management factors. Results of tested hypotheses revealed that CBIT utilisation was not influenced by respondents' personal characteristics, and no significant difference was observed in terms of level of CBIT utilization between field extension personnel (FEP) and supervisory extension personnel (SEP). It was concluded that extension personnel are constrained from using CBIT due to the prohibitive cost of CBIT software and maintenance, inappropriate infrastructure and lack of access to training opportunities. It is recommended, among others, that policy makers should facilitate the evolution of appropriate CBIT policies to enhance access to appropriate tools by extension personnel.

\section{INTRODUCTION}

Agriculture in Nigeria, like other developing countries of the world is faced with several challenges such as; the urgent need to improve agricultural productivity, ability to participate more equitably in global agricultural markets and the sustainable use of increasingly scarce natural resources. Koyenikan and Omoregbee $(2016,417)$ have listed a congruence of researchers' findings, to the effect that weak linkage between research, extension organizations, and farmers have become one of the most difficult institutional problems in most developing Nations, including Nigeria; and thereby constituting a major limiting factor to increased food productivity and sustainable development. In essence, strong linkage complimented by flawless information flow enhanced by the effective use of information and

(C) 2021 The Author(s). This is an open access article distributed under the terms of the Creative Commons Attribution License, which permits unrestricted use, distribution, and reproduction in any medium, provided the original author and source are credited. 
Underlying Factors Affecting Utilization of Computer - Based Internet Technologies by Agricultural Extension Personel in Akwa Ibom, Niger Delta, Nigeria

communication technologies (ICTs), especially the internet- based ICTs by the extension service, will significantly boost agricultural production and improve livelihood in Nigeria.

The continuous need for new information and knowledge sources in a world perceived to be information driven has been universally recognised as a spring board for increased performance of the agricultural sector. This is because there is a diversity of appropriate strategies to sustainably increase smallholder production. However, smallholder farmers in developing countries often do not have access to state-of-the-art technologies, inputs and innovations that could help increase productivity. This is due in part to the fact that availability of the facilities for official use is far from being optimal because most digital ICT facilities are unavailable and analogue ones available are not used. (Atajeromavwo 2010, 383). This brings to fore, the critical role of using information and communication technologies (ICTs) especially newer technologies such as, computer, cellular telephony and the Internet or what could be termed Computer- Based Internet Technology (CBIT) for agricultural development; which is now gaining widespread acceptance. This development reflects a need for alternative sources of information rather than face-to-face, technology-driven donor-promoted information services, which provide only one-time information to farmers and thus lessen their impact. Asenso-Okyere and Mekonnen $(2012,1)$ observed that the advent of personal computers, the Internet and mobile telephony during the last two decades have provided a much wider choice in collection, storage, processing, transmission and presentation of information in multiple formats to meet the diverse requirements and skills of people. The Internet, when connected to Ipad, iPhones, tablets, smart phones, personal computers and laptops have enabled easier access to web-based applications as; the email, web browsers, search engines and social media. Therefore, if agricultural extension personnel must achieve the task of information exchange and actively participate in the process of knowledge and skills dissemination; they must be linked and be conversant with the use of CBITs for successful retrieval, storage and dissemination / exchange of information. CBIT is believed to achieve information transfer more effectively than other communication methods in extension. ICT applications are crucial in reducing information and coordination costs. They can also increase smallholder' access to timely extension information, reduce cost of extension visits, enable more frequent two-way communication between farmers and agents, improve agents' accountability, facilitate learning from one's peers through social media networks and improve flow of relevant information between farmers', agents and researchers' (FAO 2017, 5).

The increase in the use of digital technologies has created wide scale inter and intra-sectoral beneficial impacts. There is clearly a high potential for the mobile phone, Internet and related technologies to improve rural economies. Deichman, Goyal and Mishra $(2016,21)$ asserted that a number of studies have shown encouraging impacts on overall returns received by rural producers. They however caution that these innovations often fail to scale up and achieve wider acceptance. In essence, in the quest to acquire and promote timely, accurate and location specific technologies, public-initiated extension programmes must embrace digital technologies. For enhanced success in this endeavour, they would have to contain some constraining factors. Akpabio, Okon and Inyang $(2007,270)$ adduced reasons for the poor utilization status of ICT for agricultural extension work in Nigeria's Niger Delta region to poor enabling environment and lack of access, while Akpabio $(2007,38)$ with reference to Akwa Ibom State, had proffered that public sector extension officials more frequently utilise traditional broadcast and print ICTs in their extension work. These and others, not stated, must be ameliorated. The question arises as to what is the current state of the publicly-funded extension system, in terms of use of digital technologies.

Against the above stated, an update becomes necessary, as to ascertain the extent of utilisation of CBITs in the study area. In the process, it also becomes pertinent to ascertain what factors influence utilisation of CBIT for purposes of agricultural extension work. It is against this back ground that this study sought to examine factors affecting utilization of CBIT by extension personnel in Akwa Ibom State, Nigeria; by seeking to answer research questions relating to; the personal characteristics of extension personnel in the study area, level of utilization of most utilized CBITs, and factors influencing CBIT utilization in the study area. The study also sought to determine the existence if any, of a significant relationship between personal characteristics of agricultural extension personnel and their level of CBIT utilization; and finally attempted to ascertain the existence (if any) of a significant difference in CBIT utilization levels of field and supervisory personnel in the study area. 


\section{METHODOLOGY}

This study was conducted in Akwa Ibom State, Nigeria. The State is located in the Niger Delta Basin and lies

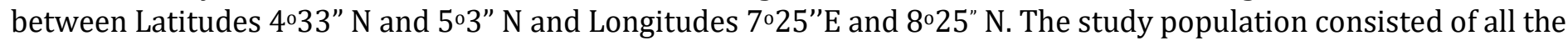
extension personnel in Akwa Ibom Agricultural Development Programme (AKADEP) which is the government agency with the mandate to provide agricultural extension services to farmers in the State. The agency operates through six zonal offices which exhibit similar organizational structure and working conditions. A well-structured and validated questionnaire was the instrument for data collection, and which was served on 196 respondents, out of which 180 set of responses were found to be valid and eventually utilised for analyses.

Some major variables were measured for the study. The first was 'level of CBIT utilization by extension agents'; which was achieved by requesting extension agents to utilise a 4-point Likert type continuum of: Not at all (1), often (2), most times (3) and always (4); to respond to a provided list of 12 relevant CBIT devices and applications. A mean value of 2.5 was used to consider the level of CBIT utilization, with $\bar{X}<2.5$, referring to low CBIT utilization while a value of $\bar{X}>2.5$ was considered high CBIT utilization. A second measured variable was; factors influencing CBIT utilization. To achieve this, a list of possible factors influencing the use of CBIT was presented to respondents, who were then requested to respond, with the aid of a 4-point Likert type continuum of: Strongly agreed $=4$, agreed $=3$, disagreed $=2$, strongly disagreed $=1$. The variables were further subjected to factor analysis.

Data analysis was done with the aid of descriptive (frequencies, percentages, means, ranks) and inferential (chisquare, t-test, factorial analysis) statistical tools.

\section{RESULTS AND DISCUSSION}

\subsection{PERSONAL CHARACTERISTICS OF RESPONDENTS}

Results in Table 1 show that $57.8 \%$ of the respondents were male while $42.2 \%$ were female. This implies that there are more male extension personnel in the study area. This trend is similar to what obtains in the Nigerian Agricultural Lawal-Adebowale and Oyekunle 2014, 143-144) and Extension system; according to a congruence of researchers' findings as reported by Oladele $(2015,33)$. Also, a large proportion $(49.4 \%)$ of the respondents was within $41-50$ years followed by $40.0 \%$ who were between $31-40$ years of age. The mean age of the respondents was 42.56 years. This suggests that most of the extension agents were in their middle age; however, the age range of 41$60(57.8 \%)$ may have implications for CBIT utilization by the respondents, since at this age respondents might be less interested in using CBIT applications (Oladele 2015, 34). Majority (91.7\%) of the respondents were married, $6.7 \%$ were single and $1.6 \%$ was widowed as presented in Table 1 . This is an indication of the value placed on marriage and the family institution in the study area.

Table 1: Personal Characteristics of Extension Agents (n: 180)

\begin{tabular}{|c|c|c|c|c|}
\hline Item & Variable & Frequency & Percentage & Mean \\
\hline 1 & Sex & & & \\
\hline & Male & 104 & 57.8 & \\
\hline & Female & 76 & 42.2 & \\
\hline 2 & Age (years) & & & \\
\hline & $21-30$ & 04 & 2.22 & 42.56 \\
\hline & $31-40$ & 72 & 40.01 & \\
\hline & $41-50$ & 89 & 49.44 & \\
\hline & $51-60$ & 15 & 8.33 & \\
\hline 3 & Marital status & & & \\
\hline & Single & 12 & 6.67 & \\
\hline & Married & 165 & 91.67 & \\
\hline & Widowed & 3 & 1.66 & \\
\hline 4 & Job Status & 6 & 3.3 & \\
\hline & Zonal Manager (ZM) & 4 & 2.2 & \\
\hline & Zonal Extension Officer (ZEO) & & \\
\hline
\end{tabular}

International Journal of Research -GRANTHAALAYAH 
Underlying Factors Affecting Utilization of Computer - Based Internet Technologies by Agricultural Extension Personel in Akwa Ibom, Niger Delta, Nigeria

\begin{tabular}{|c|c|c|c|c|}
\hline & Subject Matter Specialist (SMS) & 27 & 15.0 & \\
\hline & Block Extension Supervisor (BES) & 28 & 15.6 & \\
\hline & Block Extension Agents (BEA) & 20 & 11.1 & \\
\hline 5 & Field-level Extension Agents (FEA) & 95 & 52.8 & \\
\hline & Educational level & & & \\
\hline & OND/NCE & 46 & 25.6 & \\
\hline & HND/BSC & 116 & 64.4 & \\
\hline 6 & Household size & 18 & 10.0 & \\
\hline & 0 & & \\
\hline & $6-10$ & 88 & 48.90 & 5.76 \\
\hline & $11-15$ & 90 & 50.00 & \\
\hline & $16-20$ & 01 & 0.55 & \\
\hline 7 & Estimated monthly income level (N) & 01 & 0.55 & \\
\hline & $10,000-40,000$ & 15 & 8.33 & $73,108.92$ \\
\hline & $41,000-70,000$ & 74 & 41.11 & \\
\hline & $71,000-110,000$ & 83 & 46.11 & \\
\hline & $111,000-140,000$ & 06 & 3.33 & \\
\hline & $141,000-200,000$ & 02 & 1.12 & \\
\hline 8 & Attended Computer Training & & & \\
\hline & Yes & 67 & 37.2 & \\
\hline \multirow{2}{*}{ No } & 113 & 62.8 & \\
& Membership of professional/ cooperative groups & & 42.78 & \\
\hline & None & 57.22 & \\
\hline
\end{tabular}

Data in Table 1 also reveals that majority (63.9\%) of the respondents were Field-level Extension Personnel (FEP). This large number may indicate that AKADEP has a relatively sufficient number of field staff whose services are necessary to execute extension tasks of reaching large number of farmers in the remotely located farms and villages in the state.

Table 1 also indicates that a large proportion (64.4\%) of extension agents had B.Sc/HND as the highest level of education. This implies an educated workforce, with the assumption that extension personnel would be proactive in the utilisation of ICT devices in their quest for knowledge acquisition, in order to enhance their relevance to the solution of clientele reported/ deciphered needs. Oladele $(2015,37)$ asserted that effect of ICT on agricultural information access is improved for extension officers with higher educational qualification. In the same vein, Tata and McNamara $(2018,104)$ reported on a number of scholars who have asserted that education is imperative to the adoption and diffusion of ICTs and that educational background positively influences technological preferences and competency. They also reported that higher degree possession helps to overcome technical challenges faced in the use of ICT.

Household size of respondents shows a mean size of six members', indicating that most of the respondents had medium household sizes. Estimated monthly income level in Table 1 indicates that respondents' mean monthly income was $\$ 73,108.00$ (\$203) with a large proportion (46.11\%) earning between $\$ 71,000.00-\$ 110,000.00$. This implies that most of the personnel were earning above the national minimum wage of $18,000(\$ 50)$ per month. The result reveals that $62.8 \%$ of the respondents had not acquired any form of computer training, indicating that more than half of the respondents were non-computer literate. Tata and McNamara $(2018,104)$ have harped on the importance of the development of a vocational training program or certificate that provides the requisite level of comfort with ICT use, even with college graduates. Majority (57.2\%) of the respondents belonged to at least one professional/ cooperative organization or the other. This is a characteristic that may likely enhance communication networks and improve financial standings through savings and which may encourage the adoption of CBIT (Yakubu et al 2013, 259). 


\subsection{RESPONDENTS' LEVEL OF UTILIZATION OF CBIT APPLICATIONS}

Entries in Table 2 show the distribution of extension agents according to their level of utilization of CBIT applications. Only one of the nine CBIT items was highly utilized, and this was the Mobile phone $(\overline{\mathrm{X}}=3.56$; Rank 1$)$. The remaining eight applications were not highly utilized. This is in consonance with the findings of Enwelu (2017, 156). The three least utilised CBIT applications were: (i) I-pad/laptop (X=1.66; Rank 7); (ii) Twitter ( $\bar{X}=1.64$; Rank 8); and (iii) YouTube ( $\overline{\mathrm{X}}=1.56$; Rank 9). Implications are that majority of the selected CBIT facilities and applications were not utilised by the respondents. Akpabio $(2007,38)$ had reported that extension officials more frequently utilised traditional broadcast and print ICTs than private sector officials who utilised more of telecommunication and computer-based ICTs in their extension work.

With regard to the most utilized CBIT applications, entries in Table 2 show that $87.7 \%$ (combined value of 'most times' and 'always') of the respondents utilized mobile phones ( $\mathrm{X}=3.56$; rank 1). This implies that extension personnel in the study area can use their phones for extension work to communicate with farmers and other stakeholders, as most rural communities in the study area can be accessed on the Global System for Mobile communication (GSM) network. This is an advantage that may enhance regular communication between extension personnel and farmers. The high level of utilization of mobile phones could be attributed to the fact that it is portable, versatile, very much suited to remote areas with poor infrastructure and offer an affordable form of communication as a result of the low denomination prepaid scratch cards. The World Bank asserts that multiple Advances in the mobile telephony ecosystem engenders a "virtuous circle" of innovations (World Bank 2017, 51) that enables a number of benefits, even for smallholder farmers, including; helping to raise farmers' incomes, influencing the commercialization of farm products through increased market participation and serving as the backbone for early warning systems to mitigate agricultural risks and safeguard agricultural incomes. Other benefits include; making agricultural marketing more efficient, lowering information costs, helping to reduce transportation costs, and provision of a platform to deliver services and innovate (World Bank, 2017, 52). The fact that mobile phones, when compared with IPads/laptops, are the most used CBIT devices indicates that these were the most used devices to access social media and other web-based applications. This is a general trend regardless of vocation or status in life, and which corroborate the findings of Aromolaran, et al (2016, 101-102); Bhattacharjee and Raj (2016, 19;) and Pew Research Center $(2019,19)$ among many others. On the other hand, although Gillwald, Odufuwa and Mothobi (2018, 62) are in agreement with the above stated assertions, they however decry this trend as an evidence of the failure of the Nigerian government policy that has promoted fixed broadband access. On a general note, however, the fact that the remaining eight applications were not highly utilized by the respondents is a negative development, as this may likely debar effective and efficient exchange and sharing of ideas between extension personnel and their farmer clientele.

Also, of note (Table 2), is the low level of use of the three web applications (the web browser, search engines and the email). The email is the least utilized web application ( $\bar{X}=2.30$; Rank 5 ) since $66.1 \%$ of the study respondents do not use it, implying that majority of the respondents cannot send or receive mails through their personal or organizational e-mail addresses. This finding corroborates Uddin et al's $(2019,6006)$ report, to the effect that majority of extension agents preferred print sources, especially office materials as information sources in the course of duty performance. In essence, majority of respondents do not have access to many important useful materials and relevant, timely information available on the Internet, which assist in improved agricultural production. This implies a system that is deficient of current information (Enwelu et al., 2017, 154; Islam et al $(2017,10)$.

Of the least three utilised CBIT applications, it is evident that Majority (83.3 \%) of the respondents' do not use Ipad/laptop, making it one of the least utilized CBITs ( $\bar{X}=1.81$; Rank 7). This may be attributed to high cost of purchase, and the fact that smart phones could be utilised to provide services that otherwise may be provided by these devices. Gillwald, Odufuwa and Mothobi $(2018,62)$ reported that $75.69 \%$ Nigerian households depended on mobile devices for Internet connections, in comparison to desktops (1.36\%) or laptops (4.38\%).

Twitter ( $\overline{\mathrm{X}}=1.56$; Rank 8) and YouTube ( $\overline{\mathrm{X}}=1.64$; Rank 9) are the least utilized applications, indicating that majority of the respondents do not use them for extension activities. This situation may be attributed to lack of skills, high cost of internet subscription and fluctuating internet services. Some may even consider it as unproductive use of time. Implications are that respondents in the study area do not have access to global information, reach and audience.

In the same vein, Table 2 shows the level of utilization of Facebook, WhatsApp, Twitter and YouTube; otherwise known as Social Media (SM) platforms. The data revealed that the Face book $(\bar{X}=2.16$, rank 4$)$ is the most 
utilized SM, followed by WhatsApp ( $\bar{X}=1.93$, rank 6). The result of the analysis on these two SM platforms is consistent with global trend (Bhattacharjee and Raj, 2016, 18; Agha, Ghanghas and Chahal 2018, 1375; Pew Research Centre 2019, 13; NOI Polls, 2019; Udoidiong, 2019)), to the effect that Facebook and WhatsApp remain the most utilized SM platforms, globally.

Table 2: Distribution of respondents based on utilization of CBIT applications ( $\mathrm{n}=180)$

\begin{tabular}{|c|c|c|c|c|c|c|c|c|}
\hline S/N & Applications & Not at All \% & Occasionally \% & Most Times \% & Always \% & Mean & Rank & Remark \\
\hline 1 & Phone & 5.6 & 6.7 & 14.4 & 73.3 & 3.56 & 1 & High \\
\hline 2 & IPad, Laptop, & 57.8 & 13.9 & 17.8 & 10.6 & 1.81 & 7 & Low \\
\hline 3 & Email & 38.3 & 27.8 & 15.0 & 18.9 & 2.14 & 5 & Low \\
\hline 4 & Web browser & 40.0 & 25.0 & 12.8 & 22.2 & 2.17 & 3 & Low \\
\hline 5 & Search engine & 36.1 & 24.4 & 21.1 & 18.3 & 2.22 & 2 & Low \\
\hline 6 & Facebook & 41.1 & 22.8 & 14.4 & 21.7 & 2.16 & 4 & Low \\
\hline 7 & WhatsApp & 51.1 & 18.9 & 16.1 & 13.9 & 1.93 & 6 & Low \\
\hline 8 & Twitter & 62.2 & 18.9 & 11.7 & 7.2 & 1.64 & 8 & Low \\
\hline 9 & YouTube & 67.8 & 16.7 & 7.8 & 7.8 & 1.56 & 9 & Low \\
\hline
\end{tabular}

\subsection{LEVEL OF CBIT APPLICATIONS UTILIZATION OF EXTENSION AGENTS}

The result in Table 3 shows that a larger proportion of respondents $(62.8 \%$ - very low and low groups combined) reported a (self-rated) low level of utilization of CBIT applications, while the remainder (only 37.2\%) reported a (self-rated) high level of utilization of CBIT applications. This is in consonance with the findings of Uddin et al (2019) who reported that majority (82.5 \%) of extension workers in Edo State, Nigeria; preferred and were more familiar with print sources for information gathering in the line of duty, while only $10 \%$ ever utilized the Internet as first point of call when in need of information. The preference for printed information may not be unconnected with the ease with which extension workers could easily reach out to printed materials, as opposed to electronic materials. Similar findings were reported by Islam et al $(2017,9-10)$ for extension agents in Banglade

Table 3: Level of CBIT utilization of respondents $(n=180)$

\begin{tabular}{|c|c|c|c|}
\hline UCBIT Index Interval & CBITU Index Interpretation & Frequency & Percentage \\
\hline $0.00-0.25$ & Very Low CBIT utilization & 28 & 15.6 \\
\hline $0.26-0.50$ & Low Level CBIT utilization & 85 & 47.2 \\
\hline $0.51-0.75$ & High level of CBIT utilization & 63 & 35.0 \\
\hline $0.76-1.00$ & Very High CBIT utilization & 4 & 2.2 \\
\hline
\end{tabular}

\subsection{FACTORS INFLUENCING CBIT UTILIZATION AMONG AKADEP EXTENSION PERSONNEL}

Factor analysis using principal component technique was used to determine the factors that influence CBIT utilization. The results of the correlation matrix in Table 4 reveal the value of Kaiser-Meyer Olkin (KMO) measure of sample adequacy coefficient as 0.72 and Barlett's test of sphericity indicating a large Chi-Square (728.51) value and an associated small value of significance level $(\mathrm{p}<.05)$. These results indicate that the item matrix was meaningfully related with adequate underlying factorable components.

Table 4: KMO and Barlett's test for factors influencing CBIT utilization

\begin{tabular}{|c|c|c|}
\hline Kaiser-Meyer-Olkin Measure of Sampling Adequacy. & .723 \\
\hline Bartlett's Test of Sphericity & Approx. Chi-Square & 728.512 \\
\cline { 2 - 3 } & Df & 136 \\
\cline { 2 - 3 } & Sig. & .000 \\
\hline
\end{tabular}


The Communality Extraction Index (CEI) in Table 5 shows that all the listed items accounted for more than 55 percent variability among the items in the matrix. The result of the principal component analysis yielded 13 composite items and six components as factors influencing CBIT utilization in the study. These are as detailed below.

Factor 1: This is named financial factor because the items were related to a situation where respondents' level of CBIT utilization is influenced by the high cost of software and maintenance. This implies that the very low and low levels (62.8\%) of CBIT utilization could be attributed to finance (Aromolaran, 2016, 104; Ojesanmi et al. 2014, 39). The implication of this is that respondents in the study area are constrained from using CBIT due to the prohibitive cost of CBIT software and maintenance coupled with inadequate infrastructure (Ogbonna and Agwu 2013, 268)

Factor 2: This is tagged CBIT training factor because the items reflect concerns that specify lack of training as being a factor influencing the non-use of CBIT. Samansiri and Wanigasundera $(2014,472)$ found out that In-service training on ICT and the awareness of computer/ICT tools correlated positively with the use of ICT by extension workers. Similar results were reported by Yakubu et al. $(2013,266)$ Islam et al $(2017,10)$ and Olojede, Ifenkwe and Oparajioku $(2017,133)$. In essence, the use of various ICTs for information retrieval by the extension workers can be improved through frequent in-service training programs on ICT use and continuous updating of extension personnel on new developments in ICTs. It may be surmised that lack of training in the use of CBIT could translate to respondents having insufficient knowledge and skills, negative attitude and inadequate experience in using CBIT. Implications therefore are that as technology becomes more complex (analogue to digital), utilization by extension personnel would become constrained by illiteracy and more so, respondents may not feel confident to use CBIT for extension purposes.

Table 5: Component matrix of factors influencing respondents' CBIT utilization

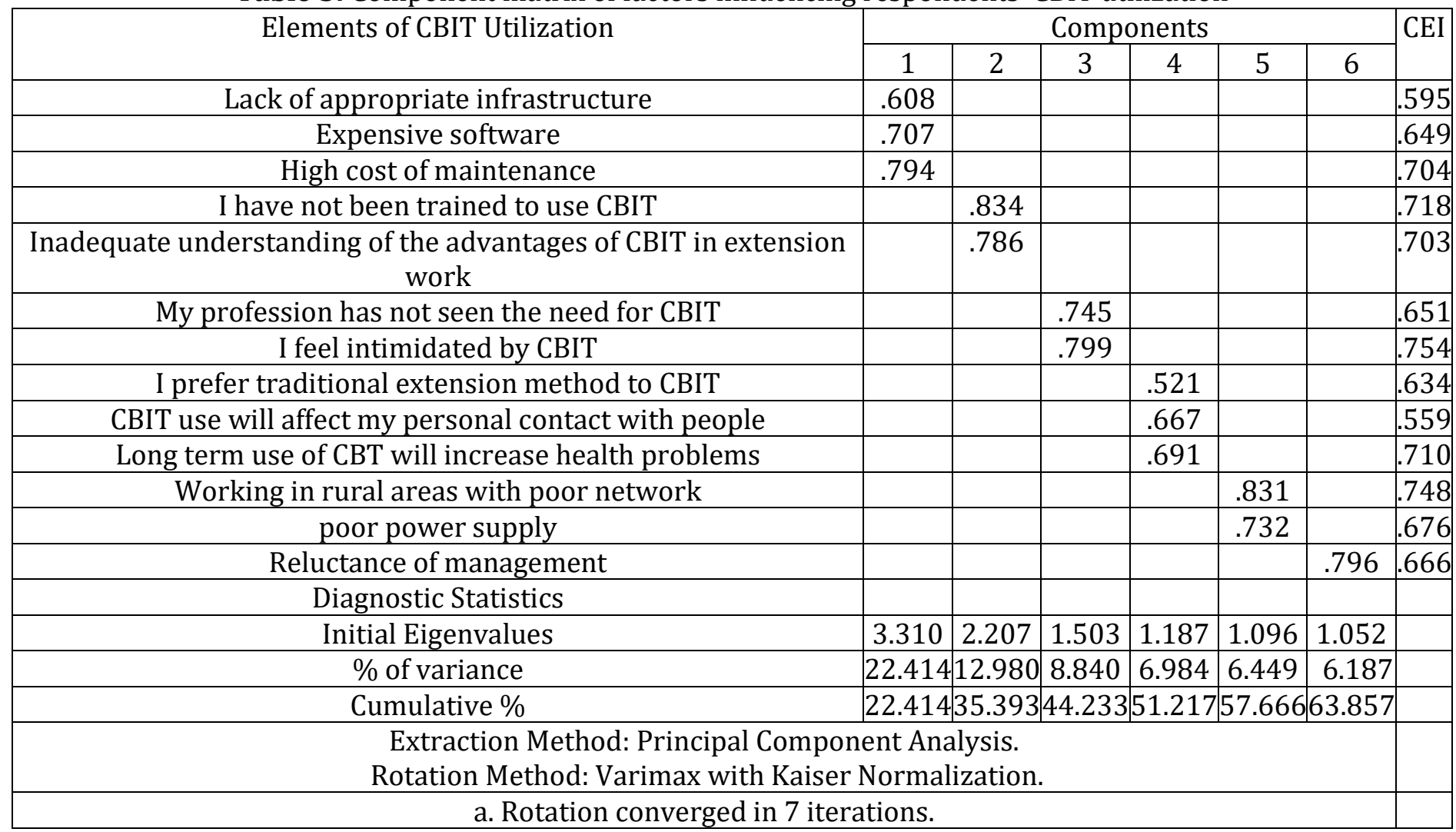

$1=$ financial, $2=$ training, $3=$ policy and personal barrier, 4=social, $5=$ technical, $6=$ managerial

Factor 3: This is tagged CBIT policy/ personal factor and the two items that loaded high under this factor include: 'My profession has not seen the need for CBIT' and. 'I feel intimidated by CBIT.' This is so tagged because the items correspond to issues of lack of policy regulations in the use of CBIT and the inherent personal barriers to the use of CBIT. Yakubu et al; $(2013,267-268)$ asserted that government policy did not favour the application of ICTs by extension workers. Issues related to lack of CBIT policy include; lack of policy support, inadequate 
Underlying Factors Affecting Utilization of Computer - Based Internet Technologies by Agricultural Extension Personel in Akwa Ibom, Niger Delta, Nigeria

regulatory environment and rigid regulations on the use of traditional means of communication. This finding is in consonance with Umar et al $(2015,73)$. Implications are that extension personnel are influenced by the existing ICT policy in the discharge of their work. In this regard Hosseini, Niknami and Nejad $(2009,1481)$ opined that liberalizing the telecommunication policy would help extension service in applying ICTs.

Factor 4: This is tagged social factor, as the items relate to respondent's perception and lack of expertise in CBIT use for extension. They indicated that these social factors include; technophobia, negative attitude towards modern technologies, inadequate understanding of the advantages and disadvantages of using ICTs, lack of social interaction and prejudice against ICTs. These findings relate to those of Aromolaran $(2016,104)$ and Bhattacharjee and Raj $(2016,19)$. Against the above-stated background, Ajayi, Alabi and Akinsola $(2013,6233)$ recommend that provision of adequate information on various relevant ICT suitable for extension service delivery to extension agents will help improve their knowledge and hence help in the development of more positive perception towards ICT use. The problem of poor perception is further influenced by $43 \%$ of the respondents who do not belong to any professional/social organization. Umar et al $(2015,72)$ had opined that belonging to professional/ social associations enhances the interaction of extension agents with others and therefore gives them more exposure to the use of ICTs. As a corollary, Ajayi, Alabi and Akinsola $(2013,6231)$ argued that extension agents with a higher ICT knowledge, tend to possess higher levels of ICT awareness, and hence, a more favourable perception towards the use of ICT devices. In the same vein, Aromolaran et al. $(2016,105)$ opined that the extension agent that uses the Internet extensively is likely to have a favourable perception of its use in innovation management.

Factor 5: This is named technical factor, as it is concerned with respondents avoiding the use of CBIT due to erratic power supply and poor network especially in rural areas where they work (Bhattacharjee and Raj (2016, 19, 23) Implications are that extension personnel are not only influenced by power outages but also poor network, since CBITs are electrical appliances that need electricity to function. Akpabio, Okon and Inyang $(2007,270)$ termed these constraints as poor enabling environment and lack of access. Indications are that respondents are unable to explore the use of CBIT due to the above-identified issues. These findings are as corroborated by Aromolaran et al $(2016,103)$ and Onkonji $(2016)$ in Gillwald, Odufuwa and Mothobi $(2018,24-25)$ who all attribute challenges of problems of network failure, congestion and irregular power supply. In this wise Hosseini, Niknami and Nejad (2009, 1481) assert that enhancing rural telecommunication Infrastructure will enhance extension agents' access to the use of ICT applications.

Factor 6: This is named managerial factor, because it is concerned with management's reluctance to encourage the use of CBIT. This implies that extension personnel in the study area will not be favourably disposed to use CBIT, unless the management directs them. A similar finding was recorded by Bhattacharjee and Raj $(2016,23)$ who asserted that institutional difficulties, including non- importance attached to ICT use by extension management can delay its development. In the same vein, Lange (2014) in Bhattacharjee and Raj (2016, 22) asserted that management's interest in the use of ICT will enhance Inter-organizational and intra-organizational communication and can result in increased interaction within the employees and with customers. Implications are that individuals would indulge in the use of a system, when they perceive that more influential people approve of its use. In essence, extension agents are yet to come to terms with the benefits of CBIT and will only change their attitude through the influence of their superior officers or perceived influential people.

\subsection{RESULTS OF TEST OF HYPOTHESES}

\subsubsection{RELATIONSHIP BETWEEN PERSONAL CHARACTERISTICS OF AKADEP PERSONNEL AND LEVEL OF CBIT UTILIZATION}

Chi-square test was conducted to examine the existence or otherwise of a relationship between some selected personal characteristics of AKADEP personnel (sex, marital status, job status, and educational level) and their level of CBIT utilization at $5 \%$ level of probability (Table 6). Implications are that: sex, marital status, job status and level of education; do not influence CBIT utilization by AKADEP extension agents. There is a divergence of researchers' findings on the above stated results. Ajayi, Alabi and Akinsola $(2031,6231)$ and Islam et al. $(2017,10)$ among others; agree with the results. On the other hand, Oladele $(2015,38-39)$ with regard to educational qualification; Tata and McNamara $(2018,106)$ with regard to education and work experience, among many others; reject the findings. With regard to CBIT use, Samansiri and Wanigasundera $(2014,471)$ found age and work experience to be negatively and

International Journal of Research -GRANTHAALAYAH 
significantly correlated to the use of both Internet and email facilities. On a conclusive advisory note however, Mousavi et al. $(2018,10)$; Samansiri and Wanigasundera $(2014,472)$ and Yakubu et al. $(2013,266-268)$ all harp on the importance of ICT training (awareness) access and purpose of use; as essential ingredients for ICT adoption.

Table 6: Test of relationship between personal characteristics of AKADEP personnel and level of CBIT utilization

\begin{tabular}{|c|c|c|c|c|c|c|c|}
\hline Item & Variables & Chi -square value & $\mathrm{df}$ & Asymp sign & P value & Remark & Decision \\
\hline 1 & Sex & $2.515^{\mathrm{a}}$ & 2 & .473 & 0.05 & Not Significant & $\mathrm{H}_{\mathrm{o}}$ : Accepted \\
2 & Marital status & $4.863^{\mathrm{a}}$ & 4 & .561 & 0.05 & Not Significant & $\mathrm{H}_{\mathrm{o}}$ : Accepted \\
3 & Job Status & $8.643^{\mathrm{a}}$ & 7 & .967 & 0.05 & Not Significant & $\mathrm{H}_{\mathrm{o}}$ : Accepted \\
4 & Educational Level & $10.400^{\mathrm{a}}$ & 4 & .109 & 0.05 & Not Significant & $\mathrm{H}_{\mathrm{o}}$ : Accepted \\
\hline
\end{tabular}

\subsection{LEVEL OF CBIT UTILIZATION BETWEEN FIELD EXTENSION PERSONNEL (FEP) AND SUPERVISORY EXTENSION PERSONNEL (SEP) OF AKADEP}

An independent-sample t-test was conducted to compare the level of CBIT utilization between FEP and SEP. The results indicated that there was a difference in the mean scores for FEP $(\bar{X}=.5370, S D=.19092)$ and SEP $(\bar{X}=.5467$, $\mathrm{SD}=.17034$ ). Implications are that the SEPs utilize CBITs at a relatively higher level than the FEPs, the difference was however not wide enough to be significant. The mean difference between the two groups of personnel (FEP and SEP) was -.00973 and the 95 percent confidence interval for the mean difference between the two groups of personnel are between .07777 and .05831 . Table 7 showed that the level of significance obtained from the analysis $(\mathrm{P}=.778)$ was greater than $(\mathrm{P}=.05)$. Thus, the null hypothesis is, therefore, accepted see Table 7 . This result contradicts related findings. Yakubu et al. $(2013,267-268)$ revealed that extension supervisors had more access and adopted more ICTs than younger extension agents; while, Samansiri and Wanigasundera $(2014,471)$ revealed that old and experienced extension workers are not much interested in the use of Internet and email facilities to search for information, in comparison to younger extension workers.

The measure of relationship (effect size) on the level of CBIT utilization between the two groups was calculated using the Cohen's (d) test. The result gave a value of 0.5; interpreted as small effect based on Duncan 's rule of thumb which states that a test whose value is $>.2-<.5$ is considered small effect. This resultant small effect is suggestive of the relative similarities in the socio-economic characteristics of both field-level and supervisory personnel of AKADEP. It is also a seeming confirmation of the fact that majority (62.8\%) of AKADEP personnel recorded low level of utilisation of CBIT devices and applications in their extension activities (Table 3). In essence, they therefore may not have much opinion on devices they hardly utilise for their work. It may however be implied that some personnel do utilise some of the devices at varying levels depending on their status in the official hierarchy of the organization. Exposure to intensive CBIT training activities, availability of CBIT equipment and ease of access to such items will enable formation of perception on these tools.

Table 7: Test of difference in the level of CBIT utilization between field extension personnel and supervisory extension personnel of AKADEP

\begin{tabular}{|c|c|c|c|c|c|c|c|}
\hline Group & Number & Mean & SD & df & T - Value & Sig & Duncan(d) \\
\hline FEP & 143 & .5370 & .19092 & 178 & -.282 & .778 & .5 \\
\hline SEP & 37 & .5467 & & & & & \\
\hline
\end{tabular}

\section{CONCLUSIONS AND RECOMMENDATIONS}

CBITs are known to facilitate extension work in the dissemination of agricultural information to a large number of beneficiaries, especially in remote areas at a relatively minimal cost. Important uses of these applications have however not been fully explored by the surveyed extension personnel who are constrained by the prohibitive cost of CBIT software and maintenance, coupled with inappropriate infrastructures which exacerbate the prevalent unpleasant situation of erratic power supply and poor Internet services. Surveyed personnel are also constrained by inherent personal barriers, inability to come to terms with the benefits of CBIT utilization, and lack of access to training opportunities. The whole scenario is compounded by supervisory officials who are also not proficient in the use of CBIT and therefore lack the capacity to advice policy makers in the formulation of appropriate CBIT policies. 
They are hence not disposed to enforce appropriate policies and regulations (if any) in aid of the development of agricultural extension. The scenario depicted above translates into a relatively large proportion of the respondents possessing general low levels of utilization of CBIT applications. Indications therefore are that the extension workforce does not have access to current agricultural innovations that abound on the internet. In essence, the generality of small-scale farmers who are generally dependent on the extension personnel for current information on technological advances in the agricultural sector are left to wallow in ignorance. They also become more constrained in their quest to access regional, national and international food markets for financial and economic empowerment purposes.

On a positive note, though; a generality of respondents utilise mobile phones for extension services. This is an advantage that could be leveraged to enhance regular communication between extension personnel and farmers. Against the above-stated background, the following recommendations are proffered.

1) Policy makers should facilitate the evolution of appropriate CBIT policies, including making computer literacy, part of a necessary requirement for employment of personnel.

2) For the existing work force, it becomes imperative to conduct a systematic assessment of training needs relative to CBITs, with particular focus on work location and length of working experience. Such assessments would assist in the development of in-service training modules for enhanced proficiency of the work force.

3) Mandatory in-service training programmes should be conducted periodically on CBIT and related training activities.

4) Financial incentives should be provided to staff to enable them procure relevant devices and applications.

5) Accessible, centrally located CBIT- friendly and well-equipped avenues should be set up, where staff could visit to get solutions to emergency and pressing problems encountered in the course of utilisation of CBIT devices and applications. These offices should be appropriately staffed and equipment therein periodically upgraded so as to be utilised by staff for development communication activities.

6) Extension personnel should also be encouraged to affiliate with professional organizations which encourage the use of CBITs. Through this, they would be motivated to improve on their level of CBIT utilization of popular applications like the search engines, browsers, emails and SM platforms. This will enhance utilization of CBITs especially as they continue to evolve.

7) Relevant NGOs, donor agencies, broadcast outfits, GSM service providers and the likes; may be utilised to assist policy makers to also sensitize extension personnel on the possible uses of CBIT for extension work and to provide necessary facilitatory assistance to augment the efforts of policy makers to provide enabling infrastructure to ease the use of CBIT.

\section{SOURCES OF FUNDING}

This research received no specific grant from any funding agency in the public, commercial, or not-for-profit sectors.

\section{CONFLICT OF INTEREST}

The author have declared that no competing interests exist.

\section{ACKNOWLEDGMENT}

None.

\section{REFERENCES}

[1] Agha, Noor., B.S. Ghanghas and Chahal, P.K. 2018. "Use of Information and Communication Technologies by Extension Personnel to Disseminate Agricultural Information”. Int.J.Curr.Microbiol.App.Sci. 7(04): 1369-1376. 
[2] doi: https://doi.org/10.20546/ijcmas.2018.704.153

[3] Ajayi, A. O., O.S.Alabi and T.O.Akinsola. 2013 "Knowledge and Perception of Extension Agents on Information and Communication Technologies (ICTs) Use in Extension Service Delivery in Ondo State, Nigeria" African Journal of Agricultural Research 8(48): 6 6233, December, DOI: 10.5897/AJAR2012.7061

[4] Akpabio, I.A 2007. "Agricultural Extension Officials and utilization of ICT in Akwa Ibom State, Nigeria" Journal of Extension Systems, India. 23 (1): 30-40. June http://www.jesonline.org/current.htm

[5] Akpabio, I.A; D. P. Okon and E.B. Inyang. 2007. “Constraints Affecting ICT Utilization by Agricultural Extension Officers in the Niger Delta, Nigeria" The Journal of Agricultural Education and Extension 13(4):263-272. December. DOI: 10.1080/13892240701630986

[6] Aromolaran, A. K., C.I. Alarima, D. Akerele, O. Oyekunle, G.A Leramo. 2016. "Use of Internet for Innovation Management by Extension Agents in Oyo State" Journal of Agricultural Extension 20 (1): 96-106. June. http://dx.doi.org/10.4314/jae.v20i1.8

[7] Asenso-Okyere, Kwadwo and Mekonnen, Daniel.A.2012. The Importance of ICTs in the Provision of Information for Improving Agricultural Productivity and Rural Incomes in Africa. UNDP Working Paper WP 2012-015: January 2012 32pp

[8] Atajeromavwo, E. J., G. Ekruyota, I. Eti, and E. Oyefia. 2010. "An Evaluation of the Relevance of Information and Communication Technologies (ICT) to Agricultural and Rural Development in Niger Delta of Nigeria" African Research Review 4(1): 374-389 January. http://dx.doi.org/10.4314/afrrev.v4i1.58258

[9] Bhattacherjee, Suchiradipta and Saravanan, Raj. 2016. Social Media: Shaping the Future of Agricultural Extension and Advisory Services. A Global Forum for Rural Advisory Services (GFRAS) Interest Group on ICT4RAS Discussion Paper, GFRAS: Lindau, Switzerland. 38 pp.

[10] Deichman, Uwe; Aparajita Goyal and Deepak Mishra 2016. Will Digital Technologies Transform Agriculture in Developing Countries? Policy Research Working Paper 7669. World Bank. May.

[11] Durojaiye, L.O, Abubakar S.Z, Omenaza Z.E, Mohammed S, Wahab A A, Ismail, F.O and Musa R.A (2013) . An Information Technology and communication based agricultural extension service delivery for Nigeria. Journal of Agricultural Extension 17(2):16-22 December http://dx.doi.org/10.4314/jae.v17i2.3

[12] Enwelu, I. A., S. O. Enwereuzor, A. N. Asadu, H. U. Nwalieji and B. C Ugwuoke. 2017. "Access and Use of Information and Communication Technologies by Extension Workers in Anambra State Agricultural Development Programme, Nigeria" Journal of Agricultural $\quad$ Extension $\quad 21 \quad$ (2): June, 152-162 https://dx.doi.org/10.4314/jae.v21i2.13

[13] FAO (2017) Information and Communication Technology (ICT) in Agriculture: A Report to the G20 Agricultural Deputies 57pp. Rome. http://www.fao.org/3/a-i7961e.pdf ISBN 978- 92-5-109979-7

[14] Koyenikan, Margaret J., and Friday E. Omoregbee. 2015. "Practitioners' Perceptions of Challenges and Effectiveness of Nigerian-Research-Extension-Farmer-Input Linkage System" Journal of Development and Communication Studies 4(2): 416-427 July. $\quad$ http: dx.doi.org/10.4314/jdcr. v412.2

[15] Gillwald, Alison; Fola Odufuwa and Onkokame Mothobi. 2018. The State of ICT in Nigeria 2017. Policy Paper no. 3, Series 5: After Access State of ICT in Nigeria https://researchictafrica.net/after-accessnigeria-state-of-ict-2017/ July 2018 NCC/IDRC.

[16] Hosseini, Seyed Jamal F., Mehrdad Niknami and Gholamreza H. Hosseini Nejad. 2009. "Policies Affecting the Application of Information and Communication Technologies by Agricultural Extension Service" American Journal of Applied Sciences 6 (8): 1478-1483, $\quad$ DOI: 10.3844/ajassp.2009.1478.1483 August

[17] Islam, M.S; M. E. Haque, M. S. I. Afrad, H. M. Abdullah and M. Z. Hoque. 2017. "Utilization of ICTs $\quad$ in Agricultural Extension Services of Bangladesh". Asian Journal of Agricultural Extension, Economics \& Sociology (AJAEES) 16(1): 1-11 https://doi.org/10.9734/AJAEES/2017/31207

[18] Lawal-Adebowale, O. A. and O.Oyekunle. (2014). "Agro-students' Appraisal of Online Registration of Academic Courses in the Federal University of Agriculture Abeokuta, Ogun State Nigeria". International Journal of Education and Development using Information and Communication Technology, 10 (4):139- 154

[19] https://www.researchgate.net/publication/301648836 
Underlying Factors Affecting Utilization of Computer - Based Internet Technologies by Agricultural Extension Personel in Akwa Ibom, Niger Delta, Nigeria

[20] Mousavi, Mina., Homayoun Farhadian, Hossein Shabanali Fami and Mohammad Chizai. 2018. "Factors Affecting the Use of ICT among Agricultural Experts and Farmers in East Azerbaijan province, Iran" Specialty Journal of Agricultural Sciences ISSN: 2412-737X Available online at www.sciarena.com, 4 (4): $1-13$

[21] NOI Polls (2019) Social media poll result release November 13, 2019 / social https://noi-polls.com/socialmedia-poll-result-release/

[22] Ogbonna, O. I and A. E. Agwu (2013) Access and use of information communication technologies by rural farmers in Enugu north senatorial zone, Enugu state. Scholarly Journal of Agricultural Science 3(7), 264-270, July. http:// www.scholarly- journals.com/SJAS

[23] Ojesanmi O.A., O.A Lawal-Adebowale, T.O.A Banmeke, and A.A Adeniran .2014. "Analysis of Agricultural Research Institutes' ICT Integration and Needs for Research Development in Southwest Zone of Nigeria". $\begin{array}{llll}\text { African Journal of Agricultural Science and Technology } & \text { (AJAST) } & 2(1): & 31-43 .\end{array}$ http://www.oceanicjournals.org/ajast ISSN 2311-5882

[24] Oladele, O. I. 2015. "Effect of Information Communication Technology (ICT) On Agricultural Information Access among Extension Officers in North West Province South Africa" S.Afr. Tydskr. Landbouvoorl. /S. Afr. J. Agric. Ext., 43. (2), 30 - 41 DOI: $\quad$ http://dx.doi.org/10.17159/2413-3221/2015/v43n2a344

[25] Olojede, J.C., G.E.Ifenkwe and J.O. Oparajioku (2017) "Factors Influencing Information and Communication Technology Use by Women Research Scientists in Universities of Agriculture in Nigeria" Journal of Agricultural Extension 21 (1):122-134 February,

[26] http://dx.doi.org/10.4314/jae.v21i1.10

[27] Pew Research Center, March 2019, "Mobile Connectivity in Emerging Economies" https://www.pewresearch.org/internet/2019/03/07/use-of-smartphones-and-social- media-iscommon-across-most-emerging-economies/

[28] Samansiri. B.A.D and W.A.D.P. Wanigasundera. 2014. "Use of Information and Communication Technology (ICT) by Extension Officers of the Tea Small Holdings Development Authority of Sri Lanka" Tropical Agricultural Research 25(4): 460-475 D0I:10.4038/tar. v2514.8054

[29] Tata, Joyous S. and Paul E. McNamara. 2018. "Impact of ICT on Agricultural Extension Services Delivery: Evidence from the Catholic Relief Services SMART Skills and Farmbook project in Kenya", The Journal of Agricultural Education and Extension 24l1): 89-110, DOI: 10.1080/1389224X.2017.1387160

[30] Ubom S., A. (2015). Levels of computer anxiety among extension personnel in Uyo Agricultural zone of Akwa Ibom State Agricultural Development programme: Unpublished Undergraduate Project, University of Uyo.

[31] Uddin, Irenonsen . Oyaimare., Agwu Ekwe Agwu and Ifeoma Quinette Anugwa. 2019. "Information Needs and Challenges of Agricultural Researchers and Extension Workers in Edo State, Nigeria" Traektoriâ Nauki = Path of Science. 2019.5 (6) 6001-6011 DOI: 10.22178/pos.47-7

[32] Udoidiong, Inemesit (2019) Here is how Nigerians are using the internet in 2019

[33] https://www.pulse.ng/bi/tech/how-nigerians-are-using-the-internet- in- 2019/kz097rg $02 / 08 / 2019$

[34] Umar, S; M. W Musa, Y. T. Olayemi and R. Suleiman. 2015. "Awareness and Use of Information and Communication Technologies among Extension Agents in Kaduna State of Nigeria" Journal of Agricultural Extension 19 (1) 66-76 June, http://dx.doi.org/10.4314.jae.v19i1.6

[35] Yakubu, D.H., B.Z. Abubakar, T.K. Atala and A. Muhammed. 2013. "Use of Information and Communication Technologies among Extension Agents in Kano State, Nigeria”. Journal of Agricultural Extension 17 (1) June. 162-173 DOI: 10.4314/jae. v17i1.16

[36] World Bank, 2017. ICT in Agriculture: Connecting Smallholders to Knowledge, Networks and Institutions. Updated Edition. DOI: 10.1596/978-1-4648-1002-2. 